\title{
PENYUSUNAN DESAIN INSTRUKSIONAL PADA PELATIHAN ANGGOTA REMAJA MASJID ASSALAFIYAH SURABAYA
}

\author{
Rina Duwi Jayanti \\ STID Al-Hadid, Surabaya \\ rnwiijayanti@gmail.com
}

\begin{abstract}
Abstrak: Pelatihan bertujuan untuk membentuk dan mengembangkan keterampilan, pengetahuan, dan sikap kerja tertentu pada sumber daya manusia agar bisa menjalankan program dengan baik. Berdasarkan evaluasi pelaksanaan program penerimaan zakat Remaja Masjid (Remas) Assalafiyah, ditemukan berbagai persoalan terkait pengetahuan, keterampilan, dan sikap kerja anggota dalam pelayanan penerimaan zakat. Studi ini bertujuan untuk menyusun desain instruksional pada pelatihan organisasi Remas Assalafiyah dalam pelayanan penerimaan zakat. Data dikumpulkan secara kualitatif dan analisis dipandu dengan teori instructional design Raymond A Noe. Hasil studi adalah desain instruksional pelatihan anggota Remas Assalafiyah yang bertujuan agar anggota memahami dan mampu melayani penerimaan zakat dengan sikap ramah, sopan, dan bertanggungjawab. Pemateri idealnya adalah ketua Remas Assalafiyah. Materi pelatihan di antaranya: wawasan tentang kriteria orang yang wajib membayar zakat, jenis-jenis zakat, cara perhitungan nisab masing-masing zakat, doa niat membayar zakat untuk diri sendiri maupun ketika diwakilkan, doa menerima zakat, serta tata cara penulisan pada kuitansi. Metode pelatihannya adalah instruksi kelas, simulasi, dan praktikum. Implementasi pelatihan diawali pertemuan pengantar dan petemuan lanjutan secara intensif. Evaluasi pelatihan dilakukan dengan metode tes dan menganalisis kualitas kinerja lewat observasi pada proses simulasi penerimaan dana zakat.

Kata kunci: Desain instruksional, Pelatihan, Remas Assalafiyah
\end{abstract}

Arranging Instructional Design for Training The Mosque Youth Members of Assalafiyah Surabaya. Abstract: A training aims to form and develop skill, knowledge, and certain work attitudes to human resource so that they can conduct programs appropriately. Based on evaluation on zakah acceptance program of mosque youth of Assalafiyah, it discovers that there are problems related to knowledge, skill, and work attitude of its members in serving the zakah acceptance. This study aims to arrange instructional design for training the mosque youth in serving the zakah acceptance. The data are collected qualitatively and analytically guided by Raymond A Noe's Instructional Design theory. It yields an instructional design aiming to understand and be able to serve the zakah acceptance in friendly, polite, and responsible manners. The ideal speaker for this training is the chief of mosque youth. The materials include: knowledge about criteria of people obligated to pay zakah, types of zakah, way to count nisab (limit) on each zakah, prayer on intending to pay zakah, prayer on accepting zakah, and procedure on writing the receipt. Its methods are class instruction, simulation, and practice. The training includes introduction and intensive advanced meetings. Its evaluation is conducted by giving a test and analyzing the work performance through observation on simulation process of accepting zakah.

Key words: Instructional design, Training, Mosque Youth of Assalafiyah 


\section{Pendahuluan}

Remaja masjid (remas) merupakan suatu organisasi perkumpulan remaja muslim yang menggunakan masjid sebagai pusat aktivitas. Melalui organisasi ini, diharapkan remaja memperoleh lingkungan yang islami serta dapat mengembangkan kreativitas. ${ }^{1}$ Peran remas diperlukan untuk mengorganisir kegiatan dakwah yang memiliki keterikatan dengan masjid. Keberadaannya dapat memberikan warna tersendiri bagi pengembangan masjid. Sebagai organisasi yang terikat dengan masjid maka peran utama remas tidak lain adalah memakmurkan masjid. Memakmurkan masjid merupakan bagian dari dakwah bilhal, yaitu dakwah untuk meningkatkan kesejahteraan dan kebahagiaan hidup umat, baik rohani, maupun jasmani. Remas diharapkan dapat menjadi penggerak pengembangan dakwah Islam dengan menjadikan masjid sebagai pusat aktivitasnya. ${ }^{2}$

Melalui program kerja remas, remaja diberikan pembinaan agar beriman, berilmu, dan beramal saleh. Pembinaan dilakukan dalam bentuk aktivitas yang menggabungkan nuansa keislaman, keilmuan, keterampilan untuk kalangan remaja dan masih relevan dengan fungsi masjid. ${ }^{3}$ Kegiatan remas diharapkan dapat menyelamatkan generasi muda dengan menanamkan nilai-nilai Islam. Sehingga masjid tidak hanya menjadi tempat ibadah, tetapi juga berperan sebagai wahana

\footnotetext{
${ }^{1}$ Deby Purnama, "Peran Remaja Masjid Al-Irma Dalam Pengembangan Dakwah di Kecamatan Sedan Sunggal," (Skripsi, UINSU Medan, 2017), 32.

2 Moh. E. Ayub, dkk., Manajemen Masjid, (Jakarta: Gema Insani Press, 1996), 9.

3 Deby Purnama, "Peran Remaja Masjid Al-Irma Dalam Pengembangan Dakwah di Kecamatan Sedan Sunggal," 32-33.
}

meningkatkan keilmuan, sosial masyarakat dalam rangka menciptakan pribadi yang berlandaskan nilai Islam. ${ }^{4}$ Untuk dapat menjalankan peran tersebut, remas sebagai sebuah organisasi memerlukan sumber daya manusia yang baik dan berkualitas. ${ }^{5}$ Salah satu upaya untuk mewujudkan kondisi sumber daya manusia yang baik dan berkualitas adalah melalui pelatihan.

Pelatihan dalam sebuah organisasi bertujuan untuk membentuk dan mengembangkan keterampilan, pengetahuan dan sikap kerja tertentu pada diri anggota sebagai sumber daya manusia (SDM), sehingga bisa menjalankan program kerja organisasi dengan baik. Pelatihan yang baik adalah yang mengacu pada upaya terencana oleh perusahaan untuk memfasilitasi pembelajaran karyawan dengan kompetensi yang terkait dengan pekerjaan. Kompetensi ini termasuk pengetahuan, keterampilan, atau perilaku yang sangat penting untuk kinerja pekerjaan yang sukses. ${ }^{6}$

Remas Assalafiyah berdiri sejak tahun 1970. Masjid Assalafiyah inilah yang menaungi kegiatan keagamaan untuk masyarakat sekitar Kedung Asem. Pada masa itu pula Remas Assalafiyah sudah mendirikan kantor remas sendiri. Hingga kini Remas Assalafiyah masih aktif dengan kegiatan rutin dan nonrutinnya. Kegiatan nonrutin ini misalnya seperti PHBI (Peringatan Hari Besar Islam).

\footnotetext{
${ }^{4}$ M. Noupal Zulmaron, dkk., "Peran Sosial Keagamaan Remaja Masjid di Kelurahan Pipa Reja Kecamatan Kemuning Palembang," Jurnal Studi Agama, Vol. 1 No. 1 (2017), 41

${ }^{5}$ Sentanoe Kertonegoro, Manajemen Organisasi, Cet ke-1, (Jakarta : PT. Widya Press, 1994), 100.

6 Raymond A Noe, Employee Training and Development, (New York: McGraw-Hill Companies, 2010), 5.
} 
Salah satu kegiatan perayaan hari besar Islam yang dikelola oleh Remas Assalafiyah adalah pengumpulan zakat dari masyarakat sekitar wilayah Kedung Asem. Namun, terselenggaranya kegiatan pengumpulan zakat ini masih menyisakan evaluasi bagi pengurus remas. Sebab di lapangan masih ditemukan persoalan-persoalan yang membuat pelaksanaan kegiatan tidak lancar, yaitu: (1) posko penerimaan zakat tidak selalu dibuka setiap hari karena tidak ada SDM yang selalu stand by menjaga posko, sehingga warga yang datang tidak selalu bisa dilayani; (2) terjadi antrian panjang ketika posko dibuka sebanyak dua orang, waktu pembagian zakat pun menjadi terlambat karena proses pengumpulan di posko berlangsung lama, untuk mengurai antrian, posko ditambah menjadi 6; ${ }^{7}$ (3) kebutuhan jumlah SDM penjaga posko penerimaan zakat yang tidak sebanding dengan ketersediaan SDM yang mampu melayani penerimaan zakat. Sejauh ini, SDM yang sudah bisa melayani penerimaan zakat hanya lima orang saja yang merupakan pengurus inti remas. Sedangkan untuk melayani penerimaan zakat perharinya membutuhkan SDM sejumlah empat orang selama tujuh hari. SDM penjaga posko dibuat berbeda setiap harinya karena tingkat kesibukan anggota yang tinggi, sehingga total SDM yang dibutuhkan untuk menjaga posko penerimaan zakat adalah 28 orang. ${ }^{8}$

Proses penerimaan zakat pun tidak mudah. Pertama-tama, penjaga posko harus bisa menyambut warga yang datang dan menanyakan keperluan pembayaran zakat yang akan diberikan. Sebab ada beberapa

7 Ketua Remas Assalafiyah dan tim, "Laporan Pertanggungjawaban Kepanitiaan Zakat," Remas Assalafiyah, Surabaya, 2017.

8 Achmad Alfarisi, wawancara oleh penulis, Remas Assalafiyah Surabaya, tanggal 8 Februari 2020. tujuan warga mendonasikan dana, seperti untuk membayar zakat mal, zakat fitrah, ataupun fidyah. Pembayaran zakat fitrah pun bisa dilakukan untuk muzaki sendiri atau untuk keluarganya, seperti istri, anak lakilaki, anak perempuan, ibu kandung, dan lainlain. Perbedaan tujuan ini akan berpengaruh pada perbedaan niat yang nanti akan dipandu oleh penjaga posko. Selanjutnya, SDM penjaga posko menerima dan membimbing muzaki untuk membaca niat membayar zakat. Selanjutnya, SDM membaca doa menerima zakat. Kemudian SDM menuliskan kuitansi. Terakhir, SDM menawarkan infak untuk panitia kepada muzaki. Jika muzaki bersedia, infak bisa dimasukkan ke dalam kotak amal. ${ }^{9}$ Di sisi lain, anggota Remas Assalafiyah yang totalnya 40 orang didominasi oleh pelajar $\mathrm{SMP}$ dan $\mathrm{SMA} / \mathrm{K}$ yang minim pengalaman organisasi dan belum pernah memiliki pengalaman membantu menerima zakat. Sehingga bisa dipastikan mereka tidak bisa melakukan proses pelayanan penerimaan dana zakat. ${ }^{10}$

Berdasarkan latar belakang masalah di atas, maka perlu dirumuskan rencana pelatihan bagi anggota Remas Assalafiyah. Studi ini adalah riset aplikasi (aplied research), karena hasil studi diharapkan untuk dapat diaplikasikan oleh pihak terkait. Pendekatannya adalah riset pengembangan (research development), dalam hal ini riset pengembangan desain instruksional sistem pelatihan. Dalam organisasi, riset pengembangan salah satu kegunaanya adalah untuk pengembangan program, ${ }^{11}$ dalam hal ini program pelatihan anggota

\footnotetext{
9 Ibid.

${ }^{10}$ Ibid.

11 Husein Umar, Desain Penelitian Manajemen Strategik, (Jakarta: Rajawali Press, 2010), 10.
} 
remas. Umumnya tahapan riset pengembangan dilakukan sampai uji coba desain atau sistem yang dihasilkan. ${ }^{12}$ Namun dalam studi ini hanya sampai tahap penyusunan desain. Data dikumpulkan dari lapangan melalui wawancara dengan ketua dan pengurus Remas Assalafiyah, serta dokumen. Analisis data dilakukan secara kualitatif. Analisis data dan perumusan rencana pelatihan dipandu oleh teori instructional design yang digagas oleh Raymond A. Noe, sehingga dapat disimpulkan rencana pelatihan yang sesuai dengan konteks masalah pada Remas Assalafiyah.

Studi terdahulu yang meneliti tema sejenis adalah, pertama, jurnal yang ditulis oleh Suci Pratiwi dengan judul rancangan model pelatihan SDM berbasis e-training dalam rangka implementasi learning organization (organisasi pembelajar). ${ }^{13}$ Subjek kajian adalah PT. Drife Solusi Integrasi. Hasil studi menunjukkan bahwa model pelatihan berbasis pelatihan elektronik bisa cocok dengan perusahaan start up. Sedangkan langkah-langkah yang dilakukan yaitu, perancangan website, pengembangan website, implementasi dan evaluasi $e$ training. Perbedaan dengan studi ini adalah subjek kajian bukan remas. Sedangkan pada studi ini, rencana pelatihan ditujukan untuk remas.

Kedua, skripsi oleh Fatimah Rohviana dengan judul deskripsi sistem pelatihan SDM

\footnotetext{
12 Sugiyono, Metode Penelitian Kuantitatif, Kualitatif, dan R \& D, (Bandung: Alfabeta, 2015), 297.

13 Suci Pratiwi, "Rancangan Model Pelatihan SDM Berbasis E-Training dalam Rangka Implementasi Learning Organization," Jurnal Manajemen Pendidikan, Vol. 7 No. 1 (2016), 1234.

${ }^{14}$ Fatimah Rohviana, "Deskripsi Sistem Pelatihan SDM Organisasi Muhammadiyah pada Kader Tingkat Darul
}

Organisasi Muhammadiyah pada kader tingkat Darul Arqam tahun 2016-2020.14 Subjek kajian adalah Organisasi Muhammadiyah. Hasil studi menunjukkan bahwa sistem pelatihan kader Muhammadiyah memiliki komponen dan unsur-unsur yang tidak masuk dalam perhitungan desain program pelatihan perusahaan pada umumnya. Pada organisasi dakwah banyak mempertimbangkan pada aspek peserta, pelatih yang berkualitas, materi pembelajaran hingga strategi pembelajaran yang diterapkan. Hal ini lah yang kurang dipertimbangkan oleh perusahaan pada umumnya. Perbedaan dengan studi ini adalah subjek kajian bukan remas. Sedangkan pada studi ini, rencana pelatihan ditujukan untuk remas.

Ketiga, tesis yang ditulis oleh Agus Susanto berjudul Analisis Keputusan Stratejik Program Open Recruitmen (Oprec) Remas Al-Akbar Surabaya. Fokus studi ini adalah pada analisis keputusan strategis program rekrutmen anggota remas, bukan pada instructional design anggota remas. Sedangkan subjek kajian sama-sama pada remas, hanya saja pada studi ini remas yang diteliti adalah Remas Al-Akbar Surabaya. ${ }^{15}$ Perbedaan dengan studi ini adalah objek kajian yaitu open recruitmen pada organisasi remas. Sedangkan pada studi ini, objek kajian adalah desain pelatihan pada remas.

Mengingat masih terbatasnya kajian tentang rencana pelatihan pada remas, maka studi

Arqam pada Tahun 2016-2020" (Skripsi, STID Al-Hadid Surabaya, 2017), 1.

${ }^{15}$ Agus Susanto, "Analisis Keputusan Stratejik Program Open Recruitmen (Oprec) Remaja Masjid Al-Akbar Surabaya," (Tesis, UIN Sunan Ampel Surabaya, Surabaya, 2017), 13. 
ini begitu penting untuk dilakukan. Studi ini bertujuan untuk menerapkan teori instructional design yang digagas oleh Raymond A. Noe pada pelatihan organisasi Remas Assalafiyah. Dari segi praksis, hasil dari studi ini diharapkan dapat menjadi inspirasi lembaga dakwah dalam penyusunan instructional design. Sedangkan dari segi teoretis, studi ini menjadi contoh konkret penyusunan instructional design pada lembaga dakwah, khususnya pada remas berdasarkan teori yang digagas oleh Raymond A. Noe. Teori tersebut berisi tentang tahapan yang harus dilalui sebuah organisasi dalam merancang pelatihan untuk memenuhi kebutuhan yang sudah ditetapkan. Mulai dari menganalisis kebutuhan pelatihan, menganalisis kesiapan pelatihan, menyusun rencana pelatihan, rencana implementasi, dan rencana evaluasi pelatihan yang dilakukan.

\section{Pelatihan Sumber Daya Manusia}

Pelatihan secara umum bertujuan untuk meningkatkan hasil-hasil organisasi dengan meningkatkan kinerja SDM dari berbagai segi, baik bersifat pengetahuan maupun peningkatan skill. Jika dirincikan tujuan pelatihan SDM ada tiga hal, yaitu pertama, meningkatkan pengetahuan anggota. Pengetahuan di sini meliputi segala sesuatu yang diketahui terkait bidang pekerjaannya. Hal ini dapat membantu memastikan bahwa SDM memiliki keterampilan-keterampilan dasar yang dibutuhkan untuk bekerja. Kedua, membantu SDM agar memahami

16 Raymond A Noe, dkk, Manajemen Sumber Daya Manusia Mencapai Keunggulan Bersaing, (Jakarta: Salemba Empat, 2010), 353.

17 Khawaja Jehanzeb dan Nadeem Ahmed Bashir,

"Training and Development Program and Its Benefits cara kerja yang efektif dalam bekerja sama tim agar memberikan kontribusi maksimal pada organisasi, menjamin keamanan kerja dan menyediakan cara-cara kerja yang baru. Ketiga, pelatihan dapat menginternalisasi nilai-nilai budaya kerja organisasi maupun sikap/perilaku individu terhadap rangsangan atau lingkungan. ${ }^{16}$

Program pelatihan SDM cenderung meningkatkan keterampilan dan komitmen organisasi, yang memberikan manfaat bagi organisasi untuk peningkatan profitabiltas, efisiensi, dan output organisasi. ${ }^{17}$ Sehingga dikatakan tujuan pelatihan tercapai adalah ketika pada akhirnya SDM sanggup menguasai pengetahuan, keterampilan (kemampuan), dan perilaku atau sikap agar bisa diterapkan pada saat menjalankan tugas kerja organisasi.

\section{Langkah-Langkah Menetapkan Desain Instruksional (Instructional Design)}

Instructional design merupakan serangkaian proses dari pengembangan pelatihan secara sistematis untuk memenuhi kebutuhan yang ditetapkan. Secara umum langkah merumuskan instructional design SDM menurut Raymond A. Noe adalah sebagai berikut: (a) menilai kebutuhan pelatihan; (b) memastikan kesiapan untuk pelatihan; dan (c) merencanakan program pelatihan.

Pertama, menganalisis kebutuhan pelatihan. Menurut Raymond A. Noe, desain

to Employee and Organization: A Conceptual Study," European Journal of Business and Management, Vol. 5 No.2, (2013), 249. 
instruksional harus secara logis dimulai dengan penilaian kebutuhan, proses mengevaluasi organisasi, karyawan individu, dan tugas karyawan untuk menentukan pelatihan seperti yang diperlukan.

Analisis kebutuhan pelatihan harus menjawab pertanyaan dalam tiga bidang luas, yakni: (1) kebutuhan organisasi, yaitu analisis tentang bagaimana organisasi melihat kebutuhan pelatihan sehubungan dengan strategi organisasi, sumber daya yang tersedia untuk pelatihan, dan dukungan manajemen untuk kegiatan pelatihan. Kebutuhan pelatihan akan bervariasi bergantung pada kebutuhan keahlian untuk menjalankan strategi atau program; (2) analisis orang atau SDM, yaitu proses untuk menentukan kebutuhan individu. Analisis kebutuhan SDM terhadap pelatihan dilakukan dengan melihat evaluasi pelaksanaan kerja dan menganalisis adakah evaluasi yang disebabkan oleh kurangnya kemampuan, sikap SDM dan motivasi dalam menjalankan tugas; (3) analisis tugas, yaitu proses mengidentifikasi tugas, pengetahuan, keterampilan, dan perilaku yang harus ditekankan saat pelatihan. Biasanya, analisis tugas dilakukan bersama dengan analisis orang karena untuk bisa mengidentifikasi kemampuan, pengetahuan dan sikap yang akan dikembangkan melalui pelatihan, perlu dianalisis berpijak pada pekerjaan atau tugas yang dilakukan oleh SDM. ${ }^{18}$

Untuk melaksanakan analisis tugas, perlu melihat terlebih dahulu tugas yang diberikan pada SDM, dan dari tugas ini dibutuhkan kompetensi apa saja terkait pengetahuan,

18 Raymond A Noe, dkk, Fundamentals of Human Resource Management, (New York: McGraw-Hill Companies, 2011), 203-206. kemampuan, dan sikapnya. Dari situ bisa dilihat adakah SDM yang bisa memenuhi kompetensi tugas tersebut, jika tidak ada maka dibutuhkan pelatihan.

Kedua, menganalisis kesiapan pelatihan. Pelatihan yang efektif tidak hanya membutuhkan program yang menangani kebutuhan nyata, tetapi juga kondisi kesiapan karyawan. Kesiapan untuk pelatihan adalah kombinasi dari karakteristik karyawan dan lingkungan kerja yang positif yang memungkinkan pelatihan. Karakteristik karyawan yang diperlukan termasuk kemampuan untuk mempelajari materi pelajaran, sikap yang menguntungkan terhadap pelatihan, dan motivasi untuk belajar. Lingkungan kerja yang positif adalah lingkungan yang mendorong pembelajaran dan menghindari campur tangan dengan program pelatihan. ${ }^{19}$

Karakteristik kesiapan karyawan dipengaruhi oleh: (a) kemampuan kognitif dasar. Agar siap untuk belajar, karyawan membutuhkan keterampilan belajar dasar, terutama kemampuan kognitif, yang mencakup kemampuan untuk menggunakan bahasa tertulis dan lisan, memecahkan masalah matematika, dan menggunakan logika untuk memecahkan masalah. Karena akan sangat susah untuk bekerja dengan orang yang tidak memiliki kemampuan dasar, yang terjadi akan ada pengasahan kemampuan dasar terlebih dahulu sebelum masuk ke pelatihan; (b) motivasi untuk belajar. SDM akan belajar lebih banyak dari program pelatihan ketika mereka sangat termotivasi untuk belajar. Motivasi yang tinggi akan muncul jika SDM percaya bahwa mereka

19 Raymond A Noe, dkk, Fundamentals of Human Resource Management, 203-206. 
dapat belajar, SDM memahami manfaat dari program pelatihan, menyadari latar belakang kebutuhan terhadap pelatihan, serta melihat kesesuaian antara pelatihan dan tujuan karir mereka. Untuk membangun motivasi belajar pada diri SDM, Manajer dapat memberikan umpan balik yang mendorong SDM, menetapkan penghargaan untuk belajar, dan berkomunikasi dengan karyawan tentang jalur karier organisasi dan kebutuhan masa depan. ${ }^{20}$

Kesiapan untuk pelatihan juga tergantung pada dua karakteristik luas dari lingkungan kerja, yakni: (a) kendala situasional, yaitu batas efektivitas pelatihan yang timbul dari situasi atau kondisi di dalam organisasi. Batasan dapat mencakup kurangnya uang untuk pelatihan, kurangnya waktu untuk pelatihan atau berlatih, dan kegagalan untuk menyediakan alat dan bahan yang tepat untuk belajar atau menerapkan pelajaran pelatihan; (b) dukungan sosial yang mengacu pada cara orang-orang organisasi mendorong pelatihan, termasuk memberikan apresiasi kepada peserta pelatihan, berbagi informasi tentang partisipasi dalam program pelatihan, dan mengekspresikan sikap positif terhadap program pelatihan organisasi. Dukungan juga dapat berasal dari rekan-rekan karyawan. Organisasi dapat secara resmi membentuk kelompok SDM yang bertemu secara teratur untuk berdiskusi tentang kemajuan mereka dalam pelatihan. Cara lain adalah dengan menerbitkan buletin dengan artikel yang relevan dengan pelatihan, mungkin termasuk wawancara dengan karyawan yang berhasil menerapkan keterampilan baru. Sehingga, organisasi

20 Ibid, 206.

21 lbid, 206-207.

22 Ibid. dapat menugaskan SDM berpengalaman sebagai mentor bagi peserta pelatihan, memberikan saran dan dukungan. ${ }^{21}$

Ketiga, merencanakan program pelatihan. Ketika penilaian kebutuhan menunjukkan perlunya pelatihan dan SDM siap untuk belajar, rencana program pelatihan perlu dirumuskan. Instructional design ini akan secara langsung berkaitan dengan kebutuhan yang diidentifikasi. Perencanaan dimulai dengan menetapkan tujuan program pelatihan. Berdasarkan tujuan tersebut, perencana memutuskan siapa yang akan memberikan pelatihan, topik apa yang akan dibahas dalam pelatihan, dan metode pelatihan apa yang akan digunakan. ${ }^{22}$

Tujuan pelatihan terbagi dalam tiga jenis: (1) meningkatkan pengetahuan anggota. Pengetahuan di sini meliputi segala sesuatu yang diketahui terkait bidang pekerjaannya. Hal ini dapat membantu memastikan bahwa SDM memiliki keterampilan-keterampilan dasar yang dibutuhkan untuk bekerja. (2) Membantu SDM agar memahami cara kerja yang efektif dalam bekerja sama tim agar memberikan kontribusi maksimal pada organisasi, menjamin keamanan kerja dan menyediakan cara-cara kerja yang baru. (3) Pelatihan dapat menginternalisasi nilai-nilai budaya kerja organisasi maupun sikap atau perilaku dalam organisasi. ${ }^{23}$

Setelah tujuan ditetapkan, perencana harus menentukan subjek yang akan melatih SDM. Subjek pelatih bisa berasal dari tiga sumber, yaitu: (1) pengawas dan manajer. Pemilihan pengawas dan manajer dalam pelatihan sangat tepat, karena mereka bisa secara

23 Raymond A Noe, dkk, Manajemen Sumber Daya Manusia Mencapai Keunggulan Bersaing, 353. 
langsung menilai kebutuhan karier pegawainya. Pengawas dan manajer bisa digunakan sebagai subjek pelatih dalam program off the job training maupun on the job training; (2) rekan kerja. Rekan kerja juga memainkan peran yang penting bagi program pelatihan dan pengembangan, karena pembelajaran seringkali terjadi melalui percakapan dengan rekan kerja yang lain. Namun menempatkan rekan kerja sebagai pelatih juga perlu mempertimbangkan beban kerja dan waktu yang cukup untuk bekerja dan melakukan pelatihan; (3) pakar, yakni orang dengan keahlian pada bidang tertentu dalam pelatihan, baik dari dalam maupun luar organisasi. Jika tidak memungkinkan untuk melatih sendiri, solusi untuk menyewa pakar bisa diperhitungkan. ${ }^{24}$

Pemilihan subjek tergantung pada kebutuhan kompetensi yang akan dilatihkan dan rencana pelaksanaan program pelatihan. Pengawas dan manajer, posisi mereka berada di perusahaan, sehingga mereka dapat berhubungan langsung dengan pegawai (dalam hal ini kader atau SDM) serta memiliki kendali atas penugasan kerja pegawai. ${ }^{25}$ Selanjutnya, perencana harus merumuskan materi pelatihan yang berkaitan secara langsung dengan kebutuhan organisasi dan tujuan pelatihan. Materi yang relevan dengan kebutuhan organisasi dan tujuan pelatihan memberi dampak efektivitas penggunaan sumber daya pelatihan dan nilai manfaat bagi peserta pelatihan. ${ }^{26}$

\footnotetext{
24 Raymond A Noe, dkk, Fundamentals of Human Resource Management, 208-209.

25 Jackson, Schuler, dan Werner, Pengelolaan Sumber Daya Manusia, (Jakarta: Salemba Empat, 2011), 26-28.
}

Setelah materi pelatihan ditetapkan, perencana harus merancang metode pelatihan. Metode pelatihan adalah caracara yang digunakan untuk pelatihan. Berbagai macam metode tersedia untuk melakukan pelatihan, yakni: (1) instruksi kelas, yaitu metode pelatihan dengan melibatkan pelatih yang mengajar dalam sebuah kelompok. Metode pelatihan ini dilakukan dengan pemberian wawasan ditambah dengan bantuan slide, diskusi, studi kasus, sesi tanya jawab, bermain peran, dan lain sebagainya. Instruksi ini adalah salah satu cara yang paling murah untuk mencapai tujuan. Instruksi kelas juga bisa dilakukan secara virtual, yakni menggunakan video conference, email, maupun pesan instan. Namun secara umum memiliki kekurangan, yakni interaksi antara pelatih dan objek sangat terbatas; (2) metode audiovisual. Metode ini tidak membutuhkan pelatih untuk menghadiri kelas, peserta bisa berlatih sendiri dengan menggunakan CD dan DVD atau dalam bentuk buku kerja. Dalam konteks lebih modern bisa menggunakan perangkat portabel seperti podcast. Pengguna pelatihan audiovisual sangat memiliki kontrol atas presentasinya. Mereka dapat meninjau materi dan mungkin dapat memperlambat atau mempercepat pembelajaran; (3) on the job training, yaitu metode pelatihan dengan cara menempatkan seorang pelatih yang memiliki pengalaman kerja dan keterampilan tertentu untuk melatih seseorang dalam mempraktikkan keterampilan di tempat kerja secara langsung. Seperti contohnya adalah magang, intruksi pekerjaan, dan rotasi pekerjaan; (4)

26 Raymond A Noe, dkk, Fundamentals of Human Resource Management, 209. 
simulasi, yaitu metode pelatihan dengan cara pelatih menghadirkan situasi yang menyerupai lapangan kerja SDM nantinya. Kemudian pelatih meminta objek pelatihan untuk merespon atau membuat keputusan dari situasi yang diciptakan. Metode ini sering digunakan pada pelatihan manajemen dan kemampuan interpersonal; (5) studi kasus. Metode ini digunakan untuk meningkatkan kemampuan berpikir analisis dan evaluasi. Metode studi kasus dilakukan dengan cara pelatih menghadirkan detail situasi kasus kemudian peserta pelatihan menganalisis atau mendiskusikannya; (6) memperagakan perilaku (praktikum). Metode pelatihan ini memberikan kesempatan kepada peserta pelatihan untuk mempraktikan kemampuan tertentu. Sebagai contoh, pelatih akan memberikan materi tentang keterampilan tertentu, kemudian peserta diberi kesempatan untuk mempraktikan dan diberi masukan terkait penampilannya; dan (7) action learning. Metode ini digunakan untuk membangun kerja sama tim. Sebuah tim akan diberikan persoalan aktual untuk dipecahkan, mereka dituntut bekerja sama mencari solusi, membuat rencana dan mengimplementasikannya. ${ }^{27}$

Selanjutnya, subjek perlu merencanakan implementasi program pelatihan. Secara umum, pelatihan yang efektif harus mengomunikasikan tujuan pembelajaran dengan jelas, menyajikan informasi dengan cara yang khas dan mudah diingat, serta membantu peserta pelatihan menghubungkan materi dengan pekerjaan mereka. Karyawan paling mungkin belajar ketika pelatihan terkait dengan pengalaman kerja dan tugas mereka saat ini. Selain itu, untuk benar-benar memahami materi pelatihan, peserta perlu diberikan kesempatan untuk melatih mempraktikkan kemampuan yang dimiliki. ${ }^{28}$

Dalam proses mempraktikkan kemampuan yang dipelajari diperlukan dukungan seperti dukungan sosial dan dukungan teknis. Bentuk pemberian dukungan sosial yaitu menekankan nilai penting pelatihan, mendorong SDM untuk datang pada program pelatihan yang sudah dirancang, dan menekankan hubungan antara materi pelatihan dengan kebutuhan SDM dalam menjalankan tugas. Selain itu, implementasi pelatihan akan semakin baik jika ditambah dengan dukungan teknis untuk mendapatkan dan membagikan informasi. ${ }^{29}$

Langkah terakhir dalam perumusan instructional design adalah merumuskan evaluasi pelatihan. Setelah program pelatihan berakhir, perlu dilakukan pengukuran capaian pelatihan. Hal-hal yang perlu diukur yaitu kepuasan peserta pelatihan terhadap program, pengetahuan atau kemampuan yang dicapai, penggunaan kemampuan, atau sikap baru dalam bekerja, dan peningkatan secara individu maupun performa organisasi. Pengukuran dapat dilakukan dengan tes tertulis, tes elektronik, maupun observasi terhadap kemampuan dan sikap kerja tertentu. ${ }^{30}$
27 Ibid, 210-218.

$28 \mathrm{Ibid}, 218$.
${ }^{29} \mathrm{Ibid}, 220$. 


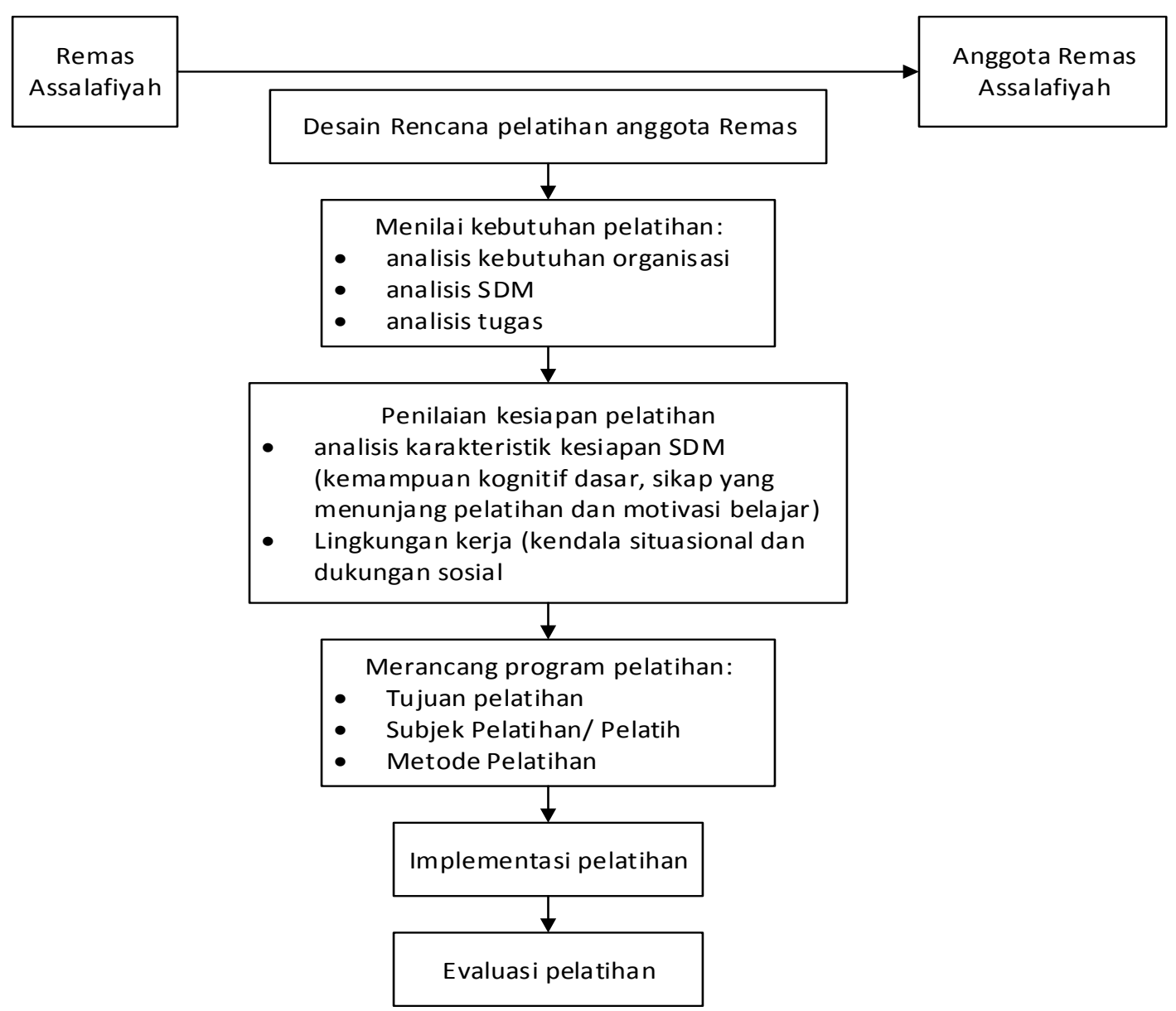

Gambar 1 - Sketsa Kerangka Berpikir Studi

\section{Gambaran Umum Remas Assalafiyah $^{31}$}

Masjid Assalafiyah berdiri sejak tahun 1970 di Kedung Asem. Masjid ini menaungi kegiatan keagamaan untuk masyarakat sekitar Kedung Asem. Dalam struktur masjid terdapat remas yang membantu untuk melaksanakan kegiatan yang dimiliki oleh masjid baik yang rutin maupun insidental. Remas Assalafiyah sendiri memiliki susunan pengurus mulai dari inti sampai dengan bidang-bidang yang spesifik.

\footnotetext{
${ }^{31}$ Achmad Alfarisi, wawancara oleh penulis, Remas Assalafiyah Surabaya, tanggal 22 Mei 2018.
}

Remas Assalafiyah memang sudah berdiri sejak tahun 1970. Namun kegiatan remas mulai diminati sekitar tahun 1990. Pada masa itu pula remas telah mendirikan kantor sekretariat sendiri yang berlokasi di samping Masjid Assalafiyah. Saat itu remas memiliki anggota aktif sebanyak 20 orang dan mengadakan berbagai kegiatan yang bersifat rutin dan nonrutin. Salah satu kegiatan nonrutin yang dilaksanakan dan cukup menarik minat remaja muslim sekitar Kedung Asem adalah kegiatan tadabur alam. 
Perkembangan Remas Assalafiyah semakin pesat ditandai dengan dibukanya amal usaha pada sekitar tahun 2000. Saat itu, Remas Assalafiyah memiliki usaha makelar rompi. Kantor remas pun ikut dijadikan lokasi usaha. Dalam waktu 3 bulan, usaha sudah memberikan keuntungan bagi kas remas. Mengikuti kegiatan remas pada akhirnya menjadi hal yang membanggakan karena secara real mampu memakmurkan Masjid Assalafiyah dengan kegiatan dan amal usahanya. Walaupun saat ini usaha makelar rompi sudah tidak lagi berjalan, namun Remas Assalafiyah tetap berusaha memakmurkan masjid dengan kegiatan rutin maupun insidental yang diselenggarakan.

Pada tahun 2017, pengurus Remas Assalafiyah menyusun anggaran dasar dan anggaran rumah tangga (AD/ART). Dalam anggaran dasar pasal 8 disebutkan bahwa "Visi Remas Assalafiyah adalah menjadi Organisasi Remas yang eksis, profesional, berakhlak mulia dan mampu memberikan rahmatan li al-alamin bagi kehidupan masyarakat di wilayah Kedung Asem Surabaya sesuai dengan nilai-nilai ahlusunnah wal jama'ah." ${ }^{32}$

Sedangkan misi Remas Assalafiyah tergambar dalam anggaran dasar pasal 9, yakni sebagai berikut: (1) melaksanakan rekrutmen remaja putra dan putri di wilayah jalan Kedung Asem Surabaya, agar memiliki kesadaran menghimpun diri dalam Remas Assalafiyah; (2) mewujudkan dan mempererat ikatan ukhuwah islamiyah antar anggota Remas Assalafiyah; (3) meningkatkan peran serta remaja muslim dan muslimah dalam partisipasi

32 Ketua Remas Assalafiyah dan tim, "Anggaran Dasar dan Anggaran Rumah Tangga," Remas Assalafiyah, Surabaya, tt, 27. memakmurkan masjid; (4) meningkatkan kualitas remaja dalam hal pengetahuan Islam, ketakwaan pada Allah, akhlak yang mulia serta kemampuan berorganisasi; (5) mengembangkan kegiatan kesenian islami, pengajian remaja, dan peringatan hari besar Islam untuk menebarkan rahmatan li alalamin bagi masyarakat sekitar; (6) mengelola keuangan Remas Assalafiyah secara amanah dan transparan untuk kepentingan program-program yang membawa rahmat bagi kemajuan Islam dan masyarakat; dan (7) membangun sistem organisasi Remas yang profesional. Visi dan misi tersebut akan menjadi pemandu akan arah gerak organisasi. Termasuk nantinya menjadi acuan program pelatihan yang akan disusun.

\section{Desain Instruksional Pelatihan Anggota Remas Assalafiyah}

\section{Analisis Kebutuhan Pelatihan}

Berdasarkan teori Raymond A. Noe, kebutuhan pelatihan akan bervariasi tergantung pada kebutuhan keahlian untuk menjalankan strategi atau program. Oleh karena itu, perlu diketahui apa saja keahlian yang dibutuhkan untuk menyukseskan program penerimaan zakat. Analisis kebutuhan pelatihan juga bisa dirumuskan dengan melihat evaluasi pelaksanaan kegiatan sebelumnya. Pada program pengumpulan dana zakat, seluruh anggota remas akan dilibatkan dalam kepanitiaan. Jika dianalisis dari proses kerja pengumpulan dana zakat, maka kualifikasi yang dibutuhkan adalah sebagai berikut: 
Tabel 1 - Analisis Kualifikasi Kebutuhan Pelatihan

\begin{tabular}{|c|c|c|c|}
\hline \multirow{2}{*}{ Aktivitas Kerja } & \multicolumn{3}{|c|}{ Kebutuhan } \\
\hline & Pengetahuan & Kemampuan & Sikap \\
\hline $\begin{array}{l}\text { Menyambut warga yang datang } \\
\text { dan menanyakan keperluan } \\
\text { pembayaran zakat yang akan } \\
\text { diberikan serta pembayaran } \\
\text { diniatkan untuk diri sendiri atau } \\
\text { mewakili anggota keluarga yang } \\
\text { lain }\end{array}$ & $\begin{array}{l}\text { Paham tentang } \\
\text { jenis zakat, nisab, } \\
\text { cara perhitungan } \\
\text { zakat, maupun } \\
\text { fidiah }\end{array}$ & $\begin{array}{l}\text { Kemampuan } \\
\text { komunikasi yang baik } \\
\text { untuk melayani } \\
\text { pembayaran dan } \\
\text { kemampuan } \\
\text { menghitung zakat } \\
\text { yang harus } \\
\text { dibayarkan }\end{array}$ & $\begin{array}{l}\text { Sopan dan ramah } \\
\text { terhadap warga } \\
\text { yang datang ke } \\
\text { posko }\end{array}$ \\
\hline $\begin{array}{l}\text { Menerima dan membimbing } \\
\text { muzaki untuk membaca niat } \\
\text { membayar zakat }\end{array}$ & $\begin{array}{l}\text { Paham jenis-jenis } \\
\text { doa membayar } \\
\text { zakat }\end{array}$ & $\begin{array}{l}\text { Mampu membaca } \\
\text { masing-masing jenis } \\
\text { doa membayar zakat } \\
\text { dengan baik sehingga } \\
\text { bisa memandu } \\
\text { muzaki }\end{array}$ & \\
\hline Membaca doa menerima zakat & $\begin{array}{l}\text { Paham doa } \\
\text { menerima zakat }\end{array}$ & $\begin{array}{l}\text { Mampu membaca } \\
\text { doa menerima zakat } \\
\text { dengan baik }\end{array}$ & \\
\hline Menuliskan kuitansi & $\begin{array}{l}\text { Paham tata cara } \\
\text { penulisan pada } \\
\text { kuitansi }\end{array}$ & $\begin{array}{l}\text { Bisa menulis dengan } \\
\text { rapi }\end{array}$ & $\begin{array}{l}\text { Jujur dan } \\
\text { bertanggungjawab } \\
\text { terhadap uang yang } \\
\text { diterima dan } \\
\text { pencatatan yang } \\
\text { dibuat }\end{array}$ \\
\hline $\begin{array}{l}\text { Menawarkan infak untuk panitia } \\
\text { kepada muzaki. Jika muzaki } \\
\text { bersedia, infak bisa langsung } \\
\text { dimasukkan ke dalam kotak amal }\end{array}$ & - & $\begin{array}{l}\text { Kemampuan } \\
\text { komunikasi yang baik }\end{array}$ & - \\
\hline
\end{tabular}

Jika dihubungkan dengan kondisi anggota Remas Assalafiyah saat ini, anggota sudah pernah menerima wawasan materi tentang jenis-jenis zakat, perhitungan nisab masingmasing jenis zakat, dan doa membayar maupun menerima zakat. Materi ini diberikan dalam tausiah oleh ketua takmir pada saat bulan Ramadan. Sehingga, secara wawasan sebenarnya anggota sudah memahami. Namun untuk bisa sampai membimbing orang lain untuk menunaikan zakat, maka perlu diberikan pengulangan lagi. Selain itu, anggota Remas Assalafiyah yang totalnya 40 orang didominasi oleh pelajar SMP dan SMA/K yang minim pengalaman organisasi dan belum pernah memiliki pengalaman membantu menerima zakat. Sehingga bisa dipastikan mereka tidak bisa melakukan proses pelayanan penerimaan dana zakat. ${ }^{33}$

\footnotetext{
${ }^{33}$ Achmad Alfarisi, wawancara oleh penulis, Remas Assalafiyah Surabaya, tanggal 13 September 2018.
} 
Sedangkan dari tinjauan evaluasi pelaksanaan program di tahun sebelumnya, ditemukan kondisi kekurangan SDM yang menjaga posko dan menimbulkan antrian yang panjang sehingga pembagian dana zakat pun terlambat. Di sisi lain, kondisi SDM yang lain belum memiliki kemampuan untuk melayani pembayaran zakat.

Sehingga dari analisis kebutuhan di atas, didapatkan beberapa kebutuhan terhadap pelatihan yang bisa dirumuskan, yakni pertama, anggota perlu memahami kembali tentang ketentuan pembayaran zakat, mulai dari kriteria orang yang wajib membayar zakat, nisab, doa niat membayar zakat untuk diri sendiri maupun ketika mewakilkan, serta doa menerima zakat. Kedua, anggota perlu dilatih untuk bisa melaksanakan aktivitas kerja penerimaan zakat mulai dari menerima muzaki yang datang hingga melayani pembayaran. Ketiga, anggota perlu dilatih agar memiliki sikap sopan, ramah, dan bertanggungjawab dalam menjalankan tugas sebagai petugas posko penerimaan zakat.

\section{Penilaian Kesiapan Pelatihan}

Berdasarkan teori Raymond A. Noe, penilaian kesiapan pelatihan dilakukan dengan cara menganalisis kesiapan SDM secara kemampuan kognitif dasar maupun kemauan untuk belajar. Selain itu, kesiapan pelatihan juga dilihat dari lingkungan sosial. Baik dari segi ada atau tidaknya kendala situasional maupun dukungan sosial terhadap program pelatihan.

Pertama, dari segi kesiapan SDM, SDM sudah memiliki kemampuan dasar dan menguasai keterampilan dasar untuk menjalankan tugas. Hal ini dapat dilihat dari latar belakang pendidikan SDM, ada yang duduk di bangku sekolah menengah pertama, sekolah menengah atas, maupun perguruan tinggi. Sehingga secara kemampuan kognitif dasar dipandang sudah memenuhi. Karena kemampuan kognitif dasar yang dimaksud pada teori adalah kemampuan membaca, berhitung, dan analisis. Dengan memiliki kemampuan dasar ini, peserta dipandang mampu menghadapi proses pelatihan yang diselenggarakan.

Dari segi kemauan belajar, anggota remas juga memiliki motivasi yang besar untuk belajar. Sebagai contoh pada saat kepanitiaan bakti sosial dan anggota Remas berperan sebagai promotor. Mereka sangat antuasias ketika diajari caranya menawarkan kegiatan ke warga. Antusiasme ditunjukkan dengan konsistensi mengikuti kegitan walaupun diadakan jam 20.30 hingga 22.00. semua anggota remas hadir dari awal hingga akhir acara, termasuk anggota perempuan. Padahal anggota juga masih disibukkan dengan kegiatan sekolah di pagi hingga sore harinya. Bahkan anggota perempuan yang terkenal pendiam juga berani untuk mempraktikkan promosi ketika sesi simulasi promosi dimulai. Setelah diklat selesai pun mereka masih mengonsultasikan kesulitannya menerapkan ilmu yang diberikan untuk mendapat arahan lebih lanjut dari Ketua Remas. Mereka juga bisa mengikuti pembelajaran dengan baik di bawah bimbingan Ketua Remas secara langsung. ${ }^{34}$

Kedua, dari segi lingkungan sosial, sejauh ini belum ditemukan kendala situasional. 
Mengingat secara infrastruktur remas sudah mencukupi. Organisasi juga memiliki kas yang bisa digunakan untuk membiayai pelatihan dan membeli infrastruktur pelatihan yang diperlukan. Remas juga mendapat dukungan penuh dari Ketua Remas dan Takmir Masjid Assalafiyah dalam hal pengembangan kualitas anggota dan kegiatan yang memajukan Remas.

Dukungan diberikan dalam bentuk pemberian alokasi dana khusus dari parkir Jumat untuk kegiatan remas. Selain itu, Ketua Takmir juga bersedia jika diminta mengisi materi untuk diklat zakat, seperti materi membaca doa zakat, hukum amil, dan hukum mustahik. Selain itu, dukungan juga diberikan oleh Ketua RT setempat. Bentuk dukungan diberikan dengan cara mendorong remaja untuk aktif di masjid. ${ }^{35}$ Sehingga dari sudut pandang kesiapan pelatihan, Remas Assalafiyah dinilai siap untuk menjalankan instructional design.

\section{Rencana Pelatihan}

Rencana pelatihan meliputi tujuan pelatihan, subjek pelatihan, topik, dan metode pelatihan. Pertama, tujuan pelatihan. Menurut teori Raymond A. Noe, tujuan pelatihan terbagi dalam tiga klasifikasi, yaitu membentuk pemahaman, kemampuan maupun sikap atau budaya kerja organisasi yang harus diterapkan.

Berdasarkan analisis kebutuhan pelatihan di atas, maka rumusan tujuan pelatihan yang relevan untuk menjawab kebutuhan organisasi Remas Assalafiyah yaitu, pertama, anggota memahami tentang ketentuan pembayaran zakat, mulai dari kriteria orang yang wajib membayar zakat, nisab, doa niat membayar zakat untuk diri sendiri maupun ketika mewakilkan, serta doa menerima zakat. Kedua, anggota mampu melaksanakan aktivitas kerja penerimaan zakat mulai dari menerima muzaki yang datang, melayani pembayaran zakat, hingga menawarkan infak untuk panitia. Ketiga, anggota memiliki sikap sopan, ramah, dan bertanggungjawab dalam menjalankan tugas sebagai petugas posko penerimaan zakat.

Penetapan tujuan pelatihan ini tidak hanya sesuai dengan kebutuhan pelatihan saja, tetapi juga sejalan dengan misi Remas Assalafiyah untuk meningkatkan kualitas remaja dalam hal pengetahuan Islam dengan memberikan wawasan tentang ketentuan pembayaran zakat, meningkatkan kualitas remaja dalam hal kemampuan berorganisasi dengan membentuk sikap tanggungjawab terhadap tugas yang diberikan. Selain itu, pemberian pelatihan penerimaan zakat yang di dalamnya ada pelatihan pencatatan keuangan juga sejalan dengan misi Remas Assalafiyah untuk membangun sistem organisasi remas yang profesional.

Kedua, subjek pelatihan. Untuk mencapai tujuan pelatihan yang diharapkan, subjek pelatih harus memiliki kemampuan komunikasi yang baik dalam melatih sehingga bisa menyampaikan materi dengan baik dan dipahami oleh objek pelatihan. Selain itu, pelatih juga harus memiliki pengetahuan terkait ketentuan pembayaran zakat, mekanisme pencatatan keuangan di internal Remas Assalafiyah, dan karakter anggota Remas Assalafiyah sehingga bisa menyampaikan materi pelatihan sesuai

35 Achmad Alfarisi, wawancara oleh penulis, Remas Assalafiyah Surabaya, tanggal 16 September 2018. 
dengan karakter dan harapan anggota Remas Assalafiyah.

Berdasarkan teori Raymond A. Noe, subjek pelatihan bisa dipilih dari manajer, rekan kerja, maupun pakar (baik eksternal dan internal). Jika dihubungkan dengan penuturan dari Ketua Remas, kondisi anggota remas yang lainnya pun dipandang masih dalam tahap yang sama yakni belum cukup kuat tanggung jawab terhadap pekerjaannya. Jika dipilih dari anggota Remas lainnya dikhawatirkan akan menurunkan kredibilitas subyek pelatihan itu sendiri. Kondisi seperti ini dapat berakibat pada kurang berjalannya proses pelatihan secara optimal.

Sedangkan peluang mencari subjek pelatih dari orang ahli di luar Remas Assalafiyah pun dinilai kurang relevan karena tujuan pelatihan sangat terikat dengan kondisi remas. Hal ini akan memberikan efek adanya kesenjangan antara pelatih dan objek yang dilatih, sehingga anggota Remas harus beradaptasi lagi dengan orang baru.

Sebagai contoh, pada tahun 2017 pernah diadakan diklat promosi dengan mengundang orang di luar organisasi Remas Assalafiyah sebagai pelatih. Namun ada evaluasi pelatih tidak memahami asumsi kondisi warga yang akan menjadi objek promosi, sehingga contoh yang disampaikan dalam pelatihan kurang relevan. Misalnya dalam proses pengenalan, umumnya subjek promosi menjelaskan tentang identitas dirinya. Tetapi dalam konteks warga Kedung Asem, identitas yang perlu dijelaskan adalah nama dan nama orang tua. Hal ini terjadi karena objek penggalangan dana yang

${ }^{36} \mathrm{Ibid}$. disasar adalah orang tua. Selain itu, pelatih dari luar pun tidak memahami karakter anggota yang diberikan pelatihan. Sehingga pelatihan berjalan kaku dan formal, padahal anggota remas menyukai suasana yang santai dan kekeluargaan. ${ }^{36}$

Ketua Remas menjadi sosok yang paling ideal untuk menjadi pelatih, karena sangat mengetahui kondisi remas dan anggota remas karena selama ini aktif mendampingi anggota dalam setiap kegiatan. Kedekatan dengan anggota terbentuk karena ketua sudah aktif di kegiatan keagamaan Kedung Asem sejak 2009 bersama dengan anggota remas lainnya. Ketua Remas Assalafiyah juga menjabat sebagai sekretaris GP Anshor Kedung Asem sejak tahun 2015 sampai sekarang, menjabat sebagai sekretaris organisasi Ishari sejak 2018 hingga sekarang, dan mengikuti kegiatan Remas Assalafiyah sejak 2014. ${ }^{37}$ Kedekatan dengan anggota menjadi modal awal penerimaan materi pelatihan yang akan disampaikan.

Tidak hanya itu, ketua juga pernah menjabat sebagai Ketua SKI sewaktu duduk di bangku sekolah menengah atas. Sehingga secara pengalaman organisasi, kemampuan dan kepemimpinan dinilai mumpuni. Selain itu, kemampuan melatih juga sudah teruji pada saat melatih anggota remas untuk mempromosikan kegiatan ke warga Kedung Asem.

Ketiga, topik pelatihan. Berdasarkan teori Raymond A. Noe, topik pelatihan harus berkaitan secara langsung untuk menjawab kebutuhan pelatihan dan tujuan pelatihan. Sedangkan dalam pelatihan ini terdapat tiga tujuan dengan karakteristik yang berbeda

37 Ibid. 
namun saling berkaitan. Contohnya, agar anggota mampu melayani penerimaan zakat, maka mereka harus paham terlebih dahulu tentang wawasan jenis-jenis zakat, cara perhitungan nisabnya, hingga doa membayar, dan menerima zakat. Sehingga untuk mencapai kedua tujuan tersebut, materi pelatihan yang harus diberikan adalah tentang kriteria orang yang wajib membayar zakat, jenis-jenis zakat, cara perhitungan masing-masing zakat, cara perhitungan fidiah, doa niat membayar zakat untuk diri sendiri maupun ketika mewakilkan, serta doa menerima zakat. Selain materi tersebut, anggota juga perlu diberikan materi tentang tata cara penulisan pada kuitansi, karena salah satu aktivitas pelayanan penerimaan dana zakat adalah menuliskan dana yang diterima pada kuitansi.

Sedangkan untuk tujuan pembentukan sikap ramah, sopan, dan bertanggungjawab tidak diberikan dalam bentuk materi, melainkan dicontohkan pada saat pelaksanaan pelatihan. Sehingga anggota memiliki gambaran yang jelas tentang sikap yang harusnya ditunjukkan saat melayani penerimaan dana zakat.

Keempat, metode pelatihan. Metode pelatihan dirumuskan berpijak pada tujuan pelatihan dan topik pelatihan yang disampaikan. Namun, metode pelatihan juga harus mempertimbangkan kesesuaian dengan objek pelatihan dan kondisi organisasi.

Metode pelatihan untuk mencapai tujuan pelatihan yang bersifat pemahaman akan dilakukan dengan metode instruksi kelas. Makna instruksi di kelas ini adalah membuat suatu forum dan dalam forum tersebut akan disampaikan materi atau topik pelatihan. Metode ini relevan untuk mencapai tujuan seluruh anggota remas memahami wawasan terkait zakat dan tata cara penulisan keuangan pada kuitansi. Dalam forum akan disampaikan topik materi yang telah disusun. Dengan asumsi anggota dan pengurus remas menyukai model penyampaian yang informal, maka ketua remas sebagai subjek pelatih perlu menyampaikan materi dengan santai. Bila perlu posisi duduk peserta dan pemateri melingkar sehingga bisa terjadi interaksi secara langsung antara subjek dan objek.

Sedangkan untuk mencapai target anggota mampu melayani penerimaan dana zakat, pelatihan perlu dilanjutkan dengan menyimulasikan proses penerimaan zakat. Artinya, setelah peserta pelatihan diberikan penjelasan tentang doa menerima zakat, kemudian peserta diminta mempraktikkan membaca doa menerima zakat sampai mereka hafal. Selanjutnya situasi didesain seolah-olah ada muzaki yang datang menyalurkan zakatnya, kemudian peserta pelatihan harus bisa merespon mulai dari menerima kedatangan muzaki, menanyakan keperluan zakat yang akan dibayarkan, menanyakan zakat yang akan dibayarkan ditujukan untuk dirinya atau mewakili anggota keluarga yang lain, kemudian membimbing muzaki untuk membaca doa membayar zakat, peserta pelatihan membaca doa menerima zakat, menuliskan kuitansi dan menawarkan infak untuk panitia jika muzaki berkenan.

\section{Rencana Implementasi Pelatihan}

Implementasi pelatihan diawali dengan anggota diberikan pertemuan khusus untuk menyampaikan tujuan pelatihan dan hubungan materi-materi yang akan 
diberikan dengan skill yang akan didapatkan. Pertemuan ini bisa dibuat sebagai pengantar sebelum dimulainya seluruh kegiatan pelatihan, sehingga seluruh anggota memahami latar belakang, tujuan, materi yang akan didapatkan dan hubungannya dalam membentuk kemampuan dan sikap yang diharapkan. Seluruh penyampaian materi juga disampaikan dengan bahasa yang tidak formal. Pada konteks anggota Remas Assalafiyah, materi dibawakan dengan bahasa Jawa sebagai bahasa seharihari yang digunakan.

Dukungan sosial dapat diberikan dengan menjelaskan manfaat yang bisa didapat ketika anggota yang akan ditugaskan menjaga posko bisa memberikan pelayanan penerimaan dana zakat dengan baik dan pengaruhnya terhadap peningkatan kepercayaan warga dalam membayar zakat ke Remas Assalafiyah. Sedangkan dukungan teknis dapat diberikan dengan memberikan wawasan terkait zakat yang akan diberikan sebagai salah satu materi pelatihan dalam bentuk makalah, sehingga anggota bisa mempelajari lebih dulu sebelum materi diberikan serta bisa lebih mudah menghafalkan doa membayar dan menerima zakat.

\section{Rencana Evaluasi Pelatihan}

Sebagaimana disampaikan Raymond A. Noe, setelah program pelatihan berakhir, perlu dilakukan pengukuran capaian pelatihan. Pada konteks pelatihan organisasi Remas Assalafiyah, tujuan pelatihan agar anggota memahami wawasan terkait zakat dapat diukur dengan metode tes. Artinya, setelah wawasan diberikan, peserta diberikan pertanyaan secara tertulis untuk mengukur sejauh mana pemahaman peserta terkait materi yang sudah diberikan.
Sedangkan untuk mencapai tujuan peserta mampu melayani penerimaan zakat, dapat diukur dari tingkat keramahan saat menyambut muzaki yang datang, apakah tiap tahapan aktivitas dijalankan atau tidak, kesesuaian jawaban peserta terhadap pertanyaan dari muzaki terkait pembayaran zakat, fasih tidaknya peserta saat membaca doa maupun saat membimbing membaca niat berzakat, serta kerapian dan kesesuaian catatan keuangan pada kuitansi dengan uang yang diterima. Sedangkan metode pengukuran bisa dilakukan dengan mengamati kualitas kinerja peserta saat melakukan simulasi maupun kinerja saat di lapangan.

\section{Kesimpulan}

Dari hasil analisis kebutuhan pelatihan ditemukan tiga kebutuhan pelatihan. Pertama, anggota perlu memahami kembali tentang ketentuan pembayaran zakat, mulai dari kriteria orang yang wajib membayar zakat, nisab, doa niat membayar zakat untuk diri sendiri maupun ketika diwakilkan, serta doa menerima zakat. Kedua, anggota perlu dilatih untuk bisa melaksanakan aktivitas kerja penerimaan zakat mulai dari menerima muzaki yang datang hingga melayani pembayaran. Ketiga, anggota perlu dilatih agar memiliki sikap sopan, ramah, dan bertanggungjawab dalam menjalankan tugas sebagai petugas posko penerimaan zakat.

Berdasarkan analisis kesiapan pelatihan, tidak ditemukan kendala situasional. Sebaliknya, anggota remas sudah memiliki kemampuan kognitif dasar untuk menerima pelatihan dan memiliki kemauan belajar. Sedangkan kondisi remas juga memiliki 
modal dana dan infrastruktur untuk mengadakan pelatihan. Ditambah adanya dukungan dari Ketua Remas dan Takmir Masjid Assalafiyah terhadap program yang dapat meningkatkan kualitas anggota Remas Assalafiyah.

Berdasarkan analisis kebutuhan pelatihan di atas, maka rumusan tujuan pelatihan yang relevan untuk menjawab kebutuhan organisasi Remas Assalafiyah yaitu, pertama, anggota memahami tentang ketentuan pembayaran zakat, mulai dari kriteria orang yang wajib membayar zakat, nisab, doa niat membayar zakat untuk diri sendiri maupun ketika diwakilkan, serta doa menerima zakat. Kedua, anggota mampu melaksanakan aktivitas kerja penerimaan zakat mulai dari menerima muzaki yang datang, melayani pembayaran zakat, hingga menawarkan infak untuk panitia. Ketiga, anggota memiliki sikap sopan, ramah, dan bertanggungjawab dalam menjalankan tugas sebagai petugas posko penerimaan zakat.

Berdasarkan analisis perumusan materi pelatihan, topik pelatihan yang disarankan yaitu wawasan tentang kriteria orang yang wajib membayar zakat, jenis-jenis zakat, cara perhitungan nisab masing-masing zakat, cara perhitungan fidiah, doa niat membayar zakat untuk diri sendiri maupun ketika diwakilkan, serta doa menerima zakat. Selain itu, peserta juga diberikan materi tentang tata cara penulisan pada kuitansi. Sedangkan subjek pelatihan yang disarankan adalah Ketua Remas Assalafiyah, karena memenuhi kriteria kemampuan komunikasi yang baik, memiliki wawasan terkait yang akan dilatihkan dan memiliki kedekatan dengan peserta pelatihan. Metode pelatihan yang relevan dengan tujuan dan topik pelatihan adalah metode instruksi kelas, praktikum dan simulasi. Metode instruksi kelas digunakan untuk mencapai tujuan anggota memahami wawasan terkait zakat dan pencatatan keuangan dari dana yang diterima. Sedangkan metode praktikum dan simulasi digunakan untuk mencapai tujuan peserta mampu melayani penerimaan zakat dengan sikap sopan, ramah, dan bertanggungjawab.

Implementasi pelatihan diawali dengan pertemuan pengantar yang berisi penyampaian tujuan pelatihan dan hubungan materi-materi yang akan diberikan dengan keterampilan yang akan didapatkan. Seluruh penyampaian materi disampaikan dengan bahasa Jawa sebagai bahasa sehari-hari yang digunakan anggota Remas Assalafiyah. Dalam hal evaluasi pelatihan, tujuan pelatihan agar peserta memahami wawasan terkait zakat akan diukur dengan metode tes. Sedangkan untuk mengukur kemampuan peserta dalam melayani penerimaan zakat akan diukur dengan metode pengamatan langsung pada saat proses simulasi dilakukan.

Hasil analisis desain instruksional pelatihan pelayanan penerimaan zakat anggota remas Assalafiyah di atas masih perlu diujicobakan, sebab sebagaimana dijelaskan di awal studi hanya sampai pada tahap penyusunan konsep desain instruksional. Untuk itu diperlukan studi lanjutan sebagai bagian dari riset pengembangan desain instruksional sistem pelatihan yang fokus pada uji coba desain instruksional pelatihan. Dari hasil uji coba akan dapat diketahui sejauh mana efektivitas dan efisiensinya, dan dapat dilakukan perbaikan apabila ada kekeliruan atau kekurangannya. Sebagai hasil rekomendasi dari studi ini, maka sangat disarankan bagi organisasi dakwah seperti 
remaja masjid, lembaga dakwah, lembaga penceramah, dan sejenisnya untuk menerapkan teori desain instruksional dalam sistem pelatihan SDM-nya, agar nantinya pelatihan dapat terlaksana dan meningkatkan kualitas SDM dari segi kemampuan, pengetahuan, dan sikap. Pelatihan dalam organisasi dakwah dapat dirancang sesuai dengan analisis kebutuhan organisasi, khususnya terkait kebutuhan
SDM untuk melaksanakan program-program organisasi. Dari situ dikembangkan sistem pelatihan mulai dari tujuan, materi, subjek, metode, rencana implementasi, dan evaluasi pelatihan. Ketika organisasi dakwah digerakkan oleh SDM-SDM berkualitas, maka harapannya pelaksanaan program akan berjalan dengan baik, sehingga penerima manfaat dari program-program dakwah akan semakin luas.

\section{Bibliografi}

Ayub, Moh. E. dkk. Manajemen Masjid. Jakarta: Gema Insani Press, 1996.

Jackson, Schuler, dan Werner. Pengelolaan Sumber Daya Manusia. Jakarta: Salemba Empat, 2011.

Jehanzeb, Khawaja dan Nadeem Ahmed Bashir. "Training and Development Program and its Benefits to Employee and Organization: A Conceptual Study." European Journal of Business and Management, Vol. 5 No. 2 (2013): 243-252. www.academia.edu/download/32182244/3947-5999-1-PB.pdf

Kertonegoro, Sentanoe. Manajemen Organisasi. Jakarta: PT. Widya Press, 1994.

Ketua Remas Assalafiyah dan tim. "Laporan Pertanggungjawaban Kepanitiaan Zakat." Surabaya: Remas Assalafiyah, 2017.

"Anggaran Dasar dan Anggaran Rumah Tangga Remas Assalafiyah." Surabaya: Remas Assalafiyah, tt.

Noe, Raymond A., dkk. Employee Training and Development. New York: McGraw-Hill Companies, 2010.

Fundamentals of Human Resource Management. New York: McGraw-Hill Companies, 2011.

Manajemen Sumber Daya Manusia Mencapai Keunggulan Bersaing. Jakarta:

Salemba Empat, 2010.

Pratiwi, Suci. "Rancangan Model Pelatihan SDM Berbasis E-Training dalam Rangka Implementasi Learning Organization.” Jurnal Manajemen Pendidikan, Vol. 7 No. 1 (2016): 1234-1243. Doi: $10.21009 / j m p .07105$

Purnama, Deby. "Peran Remaja Masjid Al-Irma Dalam Pengembangan Dakwah di Kecamatan Sedan Sunggal." Skripsi, UINSU Medan, 2017.

Rohviana, Fatimah. "Deskripsi Sistem Pelatihan SDM Organisasi Muhammadiyah pada Kader Tingkat Darul Arqam pada Tahun 2016-2020." Skripsi, STID Al-Hadid Surabaya, 2017.

Sugiyono. Metode Penelitian Kuantitatif, Kualitatif, dan R\&D. Bandung: Alfabeta, 2015.

Susanto, Agus. "Analisis Keputusan Stratejik Program Open Recruitmen (Oprec) Remas Al-Akbar Surabaya." Tesis, UIN Sunan Ampel Surabaya, 2017.

Umar, Husein. Desain Penelitian Manajemen Strategik. Jakarta: Rajawali Press, 2010. 
Rina Duwi Jayanti

Zulmaron, M. Noupal, dkk. "Peran Sosial Keagamaan Remas di Kelurahan Pipa Reja Kecamatan Kemuning Palembang." Jurnal Studi Agama, Vol. 1 No. 1 (2017): 41-54. http://jurnal.radenfatah.ac.id/index.php/jsa/article/view/1546 